\title{
Pyruvate Kinase, Inflammation and Periodontal Disease
}

\author{
Melissa M. Grant (D) \\ School of Dentistry, Institute of Clinical Sciences, University of Birmingham, 5 Mill Pool Way, Edgbaston, \\ Birmingham B5 7EG, UK; m.m.grant@bham.ac.uk
}

check for

updates

Citation: Grant, M.M. Pyruvate Kinase, Inflammation and Periodontal Disease. Pathogens 2021, 10, 784. https://doi.org/10.3390/ pathogens 10070784

Academic Editor: Ulvi Gursoy

Received: 1 May 2021

Accepted: 20 June 2021

Published: 22 June 2021

Publisher's Note: MDPI stays neutral with regard to jurisdictional claims in published maps and institutional affiliations.

Copyright: (C) 2021 by the author. Licensee MDPI, Basel, Switzerland. This article is an open access article distributed under the terms and conditions of the Creative Commons Attribution (CC BY) license (https:// creativecommons.org/licenses/by/ $4.0 /)$.

\begin{abstract}
Pyruvate kinase (PK) is the final and rate-limiting enzyme in glycolysis. It has four isoforms PKM1, PKM2, PKL and PKR. PK can form homo tetramers, dimers or monomers. The tetrameric form has the most catalytic activity; however, the dimeric form has non-canonical functions that contribute to the inflammatory response, wound healing and cellular crosstalk. This brief review explores these functions and speculates on their role in periodontal disease.
\end{abstract}

Keywords: pyruvate kinase; glycolysis; inflammation; regulation

Pyruvate kinase in the enzyme (EC 2.7.1.40) that catalyses the final step in glycolysis (Figure 1), the biochemical and metabolic pathway converting glucose to pyruvate, producing ATP and NADH. Pyruvate kinase is expressed as four isoforms in mammalian cells-PKM1, PKM2, PKL and PKR. PKL and PKR are produced by the liver and red blood cells, respectively, whilst PKM1 and PKM2 are alternative splice variants of the PKM gene. PKM1 is expressed in tissues requiring high catabolic activity, such as the heart, muscle and brain; PKM2 is expressed by proliferative cells, such as leukocytes.

The pyruvate kinase monomer is approx. $58 \mathrm{kDa}$ in size and comprises four domains: A, B, C and N. Domains A and B bind the substrates (phosphoenolpyruvate (PEP) and ADP)) and metal ions $\left(\mathrm{Mg}^{2+}\right.$ and $\left.\mathrm{K}^{+}\right)$and catalyse the reaction to produce pyruvate and ATP. PKM1 constitutively organises as a tetramer, which is efficient at catalysis without an activator. On the other hand, PKM2 requires an allosteric regulator for high activity, forming monomers $(80 \%)$, dimers $(10 \%)$ or tetramers $(10 \%)$ [1] in the absence of the allosteric regulator. Allosteric inhibitors, such as ATP, oxalate, alanine and phenylalanine, and post-translational modifications (reviewed by Prakasam et al. 2019 [2]), such as the nitrosylation of specific Cys [3], can promote the inactive dimeric and monomeric forms. The allosteric regulators bind in domain $C$, away from the catalytic site: the most well studied is fructose-1,6-bisphosphate (FBP). Five different mechanisms have been proposed for allosteric regulation (see Schormann et al. 2019 [1] for details). The possibility of modifying pyruvate kinase activity makes it a potential drug target: furthermore, although it is ubiquitous, there are differences between the control of the enzyme in different species, particularly between the kingdoms of life, making it an attractive though challenging target. The C domain also contains a nuclear localisation signal [4] sequence, and the $\mathrm{N}$ domain is very short (43 amino acids).

During inflammation, leukocytes are activated, and this causes a switch from a resting to a high metabolic state in these cells. This allows for the generation of large quantities of ATP and macromolecules required for the effector functions of immune cells: production of inflammatory mediators, rearrangement of the cytoskeleton and proliferation. PKM2 may have additional roles to that of mediating the production of pyruvate, however. In macrophages stimulated by lipopolysaccharide (LPS), PKM2 expression is induced, PKM2 translocates to the nucleus of the cells and forms a complex with transcription factor HIF1alpha, activating transcription of genes, such as IL-1beta [5], IL-6 [6] and HMGB1 [7]. Inhibition of PKM2 by shikonin or by knockdown of PKM2 expression prevents LPS driven release of these mediators [5]. In other situations, PKM2 has been shown to interact with 
tyrosine kinases, such as A-Raf, BCR-ABL and FGFR1 [8,9], RNA binding proteins, such as $\mathrm{HuR}$ and tristetraprolin, and even to Bcl-2, stabilising it during oxidative stress.

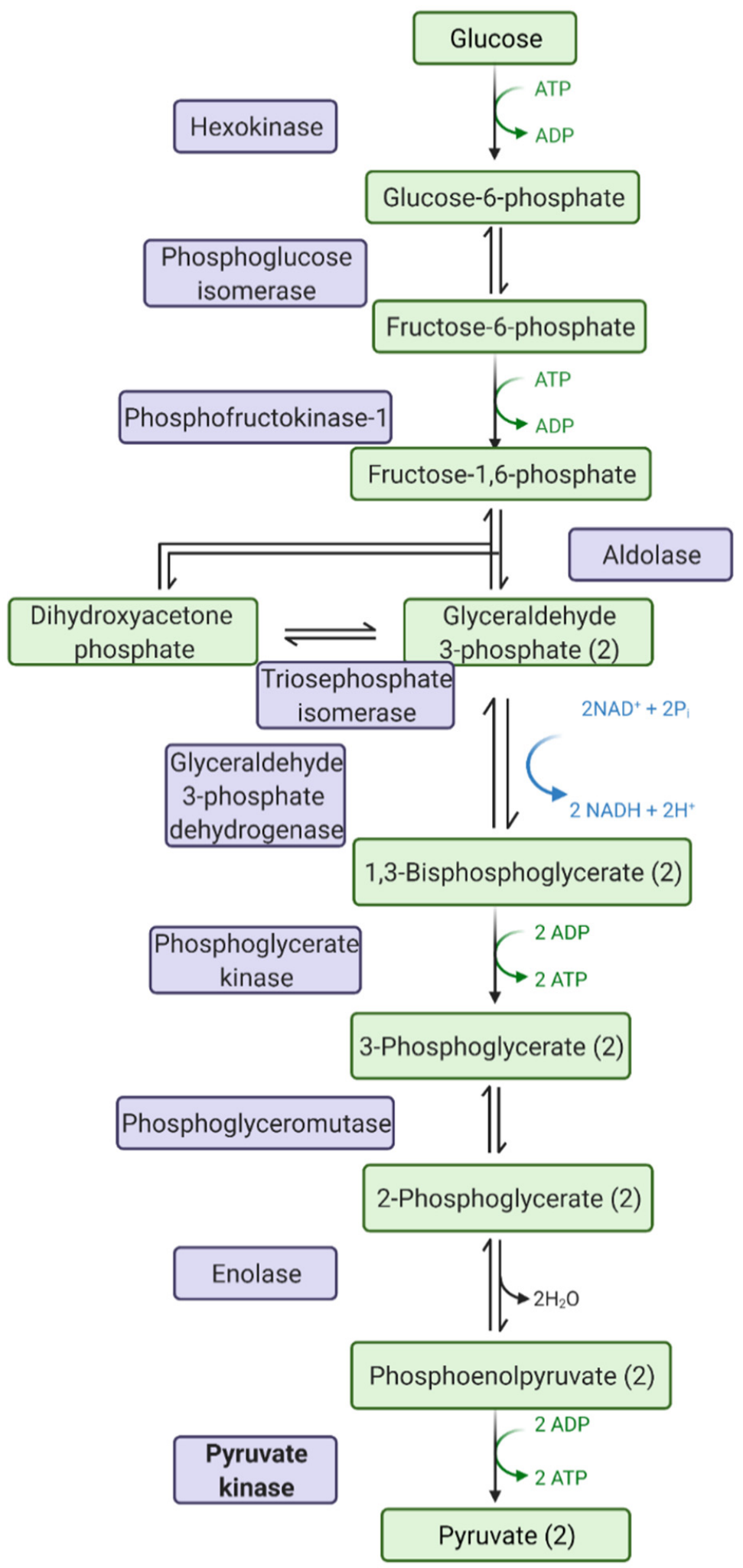

Figure 1. Steps in glycolysis: chemicals highlighted in green, and enzymes highlighted in purple. Pyruvate kinase is the last rate-limiting step in glycolysis. Image drawn with Biorender.com (accessed on 1 May 2021). 
In neutrophils, changes in glycolytic phenotype were first observed in 1959 [10], and increases in the activity of PKM2 during activation by opsonized zymosan have been specifically demonstrated [11]. In cystic fibrosis, neutrophils display an increase in aerobic glycolysis in circulation as measured by the quantity of cytosolic PKM2 in these cells [12] In response to PMA, neutrophils can form neutrophil extracellular traps (NETs): Aswathi et al. [13] explored the role of PKM2 in netosis and showed that there is a decrease in PKM2 activity but an increase in PKM2 dimerization, suggesting a non-canonical role for PKM2 in netosis. A further well-known role of neutrophils is degranulation; upon stimulation with FMLP, neutrophils degranulate and PKM2 is deposited into the extracellular space [14]. PKM2 in wounds is known to accelerate healing via the promotion of angiogenesis [14-16]. HIF1alpha is also active in neutrophils: the cells drive a hypoxic microenvironment through the great need for oxygen for energy and reactive oxygen species production. PKM2 dimers interact with and activate HIF1alpha, as mentioned before.

PKM2 has been found in overabundance in various inflammatory conditions, such as Crohn's disease [17], hepatic disorders [18], renal disease [19] and Rheumatoid Arthritis [20], as well as in a wide range of cancers [21], including oral cancers, as measured in extracellular samples, such as serum and stool. In cancer, the overabundance of PKM2 is associated with a poorer outcome [22]. Several systematic reviews have explored the use of pyruvate kinase in the diagnosis of cancers: Hathurusinghe et al. [23] concluded that PMK2 was elevated in a range of gastrointestinal malignancies; Uppara et al. [24] demonstrated that PKM2 had relatively good sensitivity (79\%) and specificity $(80 \%)$ for screening for colorectal cancer, and Wang et al. [25] determined that PKM2 had moderate performance in the diagnosis of biliary tract carcinoma.

In T cells, PKM2 is needed for T helper cells to achieve rapid differentiation, proliferation and biosynthesis [26]: upon TCR stimulation, PKM2 expression is increased [27,28]. Deletion of PKM2 inhibits the production of interferon (IFN)- $\gamma$ [29], and prevention of dimerization of PKM2 severely impacts T cell activation [30]. In B cells, PKM2 expression and enzyme activity are increased during activation [31], proliferation [32] and antibody production [33]. However, the non-canonical functions of PKM2 remain to be investigated in these cells. Intracellular signalling between lymphocytes is crucial for the immune response: extracellular vesicles are a mechanism for this crosstalk. Yang et al. [34] demonstrated that T-cell-derived ceramide-filled extracellular vesicles regulate B cell IgG production via PKM2; PKM2-null vesicles inhibited B cell activation. In a different study [35], exosomes from B cells, isolated by their expression of MHC II, contained PKM2 that coimmunoprecipitated with MHC II complexes. The association of PKM2 to the ITAM motifs on the MHC II was postulated due to the association of PKM2 to the ITAM motifs of the Fc- $\varepsilon$ RI receptor in mast cells: PKM2 is deactivated in mast cell degranulation via this interaction [36].

Periodontal diseases are chronic inflammatory diseases that share pathologies with other chronic inflammatory diseases. Periodontal diseases range from reversible gingivitis to irreversible periodontitis [37]. In the latter, destruction of the tooth-supporting tissues may eventually lead to tooth loss. Periodontitis is induced by the accumulation of a dysbiotic subgingival biofilm and exacerbated and sustained by the immune response [38]. Periodontal disease, in vivo, has been explored by the analysis of gingival crevicular fluid (GCF), which is sampled adjacent to affected teeth, and also by the analysis of saliva, which gives a more general view of the biological fluid composition of the whole mouth [39]. Proteomics, both mass spectrometry and gel-based, has been used to explore both these fluids. PKM2 has been identified in GCF of healthy people [40] and from donors with periodontitis [41-44] and gingivitis [45] in GCF and saliva. However, sometimes there is inconsistency as to whether there is more PKM2 in the healthy or inflammatory state, and it has rarely reached an increase over 2-fold. Davis et al. [44] found that PKM2 was increased in GCF from dogs naturally progressing from gingivitis to the early stages of periodontitis, whereas Bostanci et al. [41] found PKM2 in saliva to be higher in periodontitis donors. In recent work, Grant et al. (unpublished manuscript in preparation) demonstrated that PKM2 
increased modestly in gingivitis but decreased in periodontitis in saliva. These data suggest that there is tight control on PKM2 in extracellular spaces within the mouth and that there is a biphasic release related to the severity or chronicity of the inflammation. However, there is no doubt about the contribution of the immune system to periodontal disease. Thorbert-Mros et al. [46] visualised the composition of gingival biopsies from chronic gingivitis and chronic periodontitis patients by immunohistochemistry for plasma cells, macrophages, neutrophils, $\mathrm{B}$ cells and T cells; demonstrating an expansion of all cell types and an overabundance of plasma cells in periodontitis. Li et al. [47], using a bioinformatic approach, classified transcriptomic data by CIBERSORT analysis into different immune cell subsets. They concluded that the transcript signatures identified more plasma cells, naive B cells and neutrophils in periodontitis versus healthy gingival biopsies. Neutrophils release PKM2 during the initial stages of inflammation, and this contributes to wound repair [14]: this may give rise to increases in gingivitis but not in periodontitis. However, this is speculation at this point. Neutrophils will also migrate through the periodontal tissues into the oral cavity, where they can be isolated from oral rinses as oral neutrophils. The transcriptome of oral neutrophils has been explored by Lakschevitz et al. [48] demonstrating a shift to a pro-survival phenotype in periodontal disease and transcriptomics of peripheral blood neutrophils stimulated with periodontopathogen Fusobacterium nucleatum has shown increases in hexokinase [49] but not in PKM2. Changes in activity may alter without changes in expression, however there are no reports yet on this. Thus, overall, there is a lack of information of the role of PKM2 in periodontal disease and there is a need to explore further the contribution of PKM2 to periodontal health and disease.

Funding: This research received no external funding.

Conflicts of Interest: M.M.G. has no conflict of interest to declare.

\section{References}

1. Schormann, N.; Hayden, K.L.; Lee, P.; Banerjee, S.; Chattopadhyay, D. An overview of structure, function, and regulation of pyruvate kinases. Protein Sci. 2019, 28, 1771-1784. [CrossRef] [PubMed]

2. Prakasam, G.; Iqbal, M.A.; Bamezai, R.N.K.; Mazurek, S. Posttranslational Modifications of Pyruvate Kinase M2: Tweaks that Benefit Cancer. Front. Oncol 2018, 8, 22. [CrossRef]

3. Mitchell, A.R.; Yuan, M.; Morgan, H.P.; McNae, I.W.; Blackburn, E.A.; Le Bihan, T.; Homem, R.A.; Yu, M.; Loake, G.J.; Michels, P.A.; et al. Redox regulation of pyruvate kinase M2 by cysteine oxidation and S-nitrosation. Biochem. J. 2018, 475, 3275-3291. [CrossRef]

4. Yang, W.; Zheng, Y.; Xia, Y.; Ji, H.; Chen, X.; Guo, F.; Lyssiotis, C.A.; Aldape, K.; Cantley, L.C.; Lu, Z. ERK1/2-dependent phosphorylation and nuclear translocation of PKM2 promotes the Warburg effect. Nat. Cell Biol. 2012, 14, 1295-1304. [CrossRef]

5. Palsson-McDermott, E.M.; Curtis, A.M.; Goel, G.; Lauterbach, M.A.; Sheedy, F.J.; Gleeson, L.E.; van den Bosch, M.W.; Quinn, S.R.; Domingo-Fernandez, R.; Johnston, D.G.; et al. Pyruvate kinase M2 regulates Hif-1alpha activity and IL-1beta induction and is a critical determinant of the warburg effect in LPS-activated macrophages. Cell Metab 2015, 21, 65-80. [CrossRef]

6. Yang, L.; Xie, M.; Yang, M.; Yu, Y.; Zhu, S.; Hou, W.; Kang, R.; Lotze, M.T.; Billiar, T.R.; Wang, H.; et al. PKM2 regulates the Warburg effect and promotes HMGB1 release in sepsis. Nat. Commun. 2014, 5, 4436. [CrossRef]

7. Shirai, T.; Nazarewicz, R.R.; Wallis, B.B.; Yanes, R.E.; Watanabe, R.; Hilhorst, M.; Tian, L.; Harrison, D.G.; Giacomini, J.C.; Assimes, T.L.; et al. The glycolytic enzyme PKM2 bridges metabolic and inflammatory dysfunction in coronary artery disease. J. Exp. Med. 2016, 213, 337-354. [CrossRef]

8. Mazurek, S.; Drexler, H.C.; Troppmair, J.; Eigenbrodt, E.; Rapp, U.R. Regulation of pyruvate kinase type M2 by A-Raf: A possible glycolytic stop or go mechanism. Anticancer Res. 2007, 27, 3963-3971.

9. Hitosugi, T.; Kang, S.; Vander Heiden, M.G.; Chung, T.W.; Elf, S.; Lythgoe, K.; Dong, S.; Lonial, S.; Wang, X.; Chen, G.Z.; et al. Tyrosine phosphorylation inhibits PKM2 to promote the Warburg effect and tumor growth. Sci Signal. 2009, 2, ra73. [CrossRef]

10. Sbarra, A.J.; Karnovsky, M.L. The biochemical basis of phagocytosis. I. Metabolic changes during the ingestion of particles by polymorphonuclear leukocytes. J. Biol. Chem. 1959, 234, 1355-1362. [CrossRef]

11. Lane, T.A.; Beutler, E.; West, C.; Lamkin, G. Glycolytic enzymes of stored granulocytes. Transfusion 1984, 24, 153-156. [CrossRef]

12. McElvaney, O.J.; Zaslona, Z.; Becker-Flegler, K.; Palsson-McDermott, E.M.; Boland, F.; Gunaratnam, C.; Gulbins, E.; O’Neill, L.A.; Reeves, E.P.; McElvaney, N.G. Specific Inhibition of the NLRP3 Inflammasome as an Antiinflammatory Strategy in Cystic Fibrosis. Am. J. Respir. Crit. Care Med. 2019, 200, 1381-1391. [CrossRef]

13. Awasthi, D.; Nagarkoti, S.; Sadaf, S.; Chandra, T.; Kumar, S.; Dikshit, M. Glycolysis dependent lactate formation in neutrophils: A metabolic link between NOX-dependent and independent NETosis. Biochim. Biophys. Acta Mol. Basis. Dis. 2019, $1865,165542$. [CrossRef] [PubMed] 
14. Zhang, Y.; Li, L.; Liu, Y.; Liu, Z.R. PKM2 released by neutrophils at wound site facilitates early wound healing by promoting angiogenesis. Wound Repair. Regen. 2016, 24, 328-336. [CrossRef] [PubMed]

15. Li, L.; Zhang, Y.; Qiao, J.; Yang, J.J.; Liu, Z.R. Pyruvate kinase M2 in blood circulation facilitates tumor growth by promoting angiogenesis. J. Biol. Chem. 2014, 289, 25812-25821. [CrossRef] [PubMed]

16. Seignez, C.; Phillipson, M. The multitasking neutrophils and their involvement in angiogenesis. Curr. Opin. Hematol. 2017, 24, 3-8. [CrossRef] [PubMed]

17. Tang, Q.; Ji, Q.; Xia, W.; Li, L.; Bai, J.; Ni, R.; Qin, Y. Pyruvate kinase M2 regulates apoptosis of intestinal epithelial cells in Crohn's disease. Dig. Dis. Sci. 2015, 60, 393-404. [CrossRef] [PubMed]

18. Meoli, L.; Gupta, N.K.; Saeidi, N.; Panciotti, C.A.; Biddinger, S.B.; Corey, K.E.; Stylopoulos, N. Nonalcoholic fatty liver disease and gastric bypass surgery regulate serum and hepatic levels of pyruvate kinase isoenzyme M2. Am. J. Physiol. Endocrinol. Metab 2018, 315, E613-E621. [CrossRef]

19. Cheon, J.H.; Kim, S.Y.; Son, J.Y.; Kang, Y.R.; An, J.H.; Kwon, J.H.; Song, H.S.; Moon, A.; Lee, B.M.; Kim, H.S. Pyruvate Kinase M2: A Novel Biomarker for the Early Detection of Acute Kidney Injury. Toxicol. Res. 2016, 32, 47-56. [CrossRef]

20. Li, X.J.; Xu, M.; Zhao, X.Q.; Zhao, J.N.; Chen, F.F.; Yu, W.; Gao, D.Y.; Luo, B. Proteomic analysis of synovial fibroblast-like synoviocytes from rheumatoid arthritis. Clin. Exp. Rheumatol. 2013, 31, 552-558.

21. Iqbal, M.A.; Gupta, V.; Gopinath, P.; Mazurek, S.; Bamezai, R.N. Pyruvate kinase M2 and cancer: An updated assessment. FEBS Lett. 2014, 588, 2685-2692. [CrossRef] [PubMed]

22. Lim, J.Y.; Yoon, S.O.; Seol, S.Y.; Hong, S.W.; Kim, J.W.; Choi, S.H.; Cho, J.Y. Overexpression of the M2 isoform of pyruvate kinase is an adverse prognostic factor for signet ring cell gastric cancer. World J. Gastroenterol. 2012, 18, 4037-4043. [CrossRef] [PubMed]

23. Hathurusinghe, H.R.; Goonetilleke, K.S.; Siriwardena, A.K. Current status of tumor M2 pyruvate kinase (tumor M2-PK) as a biomarker of gastrointestinal malignancy. Ann. Surg. Oncol. 2007, 14, 2714-2720. [CrossRef] [PubMed]

24. Uppara, M.; Adaba, F.; Askari, A.; Clark, S.; Hanna, G.; Athanasiou, T.; Faiz, O. A systematic review and meta-analysis of the diagnostic accuracy of pyruvate kinase M2 isoenzymatic assay in diagnosing colorectal cancer. World J. Surg. Oncol. 2015, 13, 48. [CrossRef] [PubMed]

25. Wang, W.Q.; Liu, W.; Zhang, N.; Wang, P.H.; Cao, J.Z.; Chen, J.M.; Li, B.L.; He, X.D. The Diagnostic Value of Pyruvate Kinase Isoenzyme Type M2 for Biliary Tract Carcinoma. A Systematic Review and Meta-Analysis. J. Gastrointestin. Liver Dis. 2018, 27, 73-81. [CrossRef]

26. Kono, M.; Maeda, K.; Stocton-Gavanescu, I.; Pan, W.; Umeda, M.; Katsuyama, E.; Burbano, C.; Orite, S.Y.K.; Vukelic, M.; Tsokos, M.G.; et al. Pyruvate kinase M2 is requisite for Th1 and Th17 differentiation. JCI Insight 2019, 4. [CrossRef] [PubMed]

27. Wang, R.; Dillon, C.P.; Shi, L.Z.; Milasta, S.; Carter, R.; Finkelstein, D.; McCormick, L.L.; Fitzgerald, P.; Chi, H.; Munger, J.; et al. The transcription factor Myc controls metabolic reprogramming upon T lymphocyte activation. Immunity 2011, 35, 871-882. [CrossRef]

28. Cao, Y.; Rathmell, J.C.; Macintyre, A.N. Metabolic reprogramming towards aerobic glycolysis correlates with greater proliferative ability and resistance to metabolic inhibition in CD8 versus CD4 T cells. PLoS ONE 2014, 9, e104104. [CrossRef]

29. Lu, S.; Deng, J.; Liu, H.; Liu, B.; Yang, J.; Miao, Y.; Li, J.; Wang, N.; Jiang, C.; Xu, Q.; et al. PKM2-dependent metabolic reprogramming in CD4(+) $\mathrm{T}$ cells is crucial for hyperhomocysteinemia-accelerated atherosclerosis. J. Mol. Med. 2018, 96, 585-600. [CrossRef]

30. Angiari, S.; Runtsch, M.C.; Sutton, C.E.; Palsson-McDermott, E.M.; Kelly, B.; Rana, N.; Kane, H.; Papadopoulou, G.; Pearce, E.L.; Mills, K.H.G.; et al. Pharmacological Activation of Pyruvate Kinase M2 Inhibits CD4(+) T Cell Pathogenicity and Suppresses Autoimmunity. Cell Metab 2020, 31, 391-405.e398. [CrossRef]

31. Deng, J.; Lu, S.; Liu, H.; Liu, B.; Jiang, C.; Xu, Q.; Feng, J.; Wang, X. Homocysteine Activates B Cells via Regulating PKM2Dependent Metabolic Reprogramming. J. Immunol. 2017, 198, 170-183. [CrossRef] [PubMed]

32. Caro-Maldonado, A.; Wang, R.; Nichols, A.G.; Kuraoka, M.; Milasta, S.; Sun, L.D.; Gavin, A.L.; Abel, E.D.; Kelsoe, G.; Green, D.R.; et al. Metabolic reprogramming is required for antibody production that is suppressed in anergic but exaggerated in chronically BAFF-exposed B cells. J. Immunol. 2014, 192, 3626-3636. [CrossRef] [PubMed]

33. Kunisawa, J.; Sugiura, Y.; Wake, T.; Nagatake, T.; Suzuki, H.; Nagasawa, R.; Shikata, S.; Honda, K.; Hashimoto, E.; Suzuki, Y.; et al. Mode of Bioenergetic Metabolism during B Cell Differentiation in the Intestine Determines the Distinct Requirement for Vitamin B1. Cell Rep. 2015, 13, 122-131. [CrossRef]

34. Yang, J.; Dang, G.; Lu, S.; Liu, H.; Ma, X.; Han, L.; Deng, J.; Miao, Y.; Li, X.; Shao, F.; et al. T-cell-derived extracellular vesicles regulate B-cell IgG production via pyruvate kinase muscle isozyme 2. FASEB J. 2019, 33, 12780-12799. [CrossRef] [PubMed]

35. Buschow, S.I.; van Balkom, B.W.; Aalberts, M.; Heck, A.J.; Wauben, M.; Stoorvogel, W. MHC class II-associated proteins in B-cell exosomes and potential functional implications for exosome biogenesis. Immunol. Cell Biol. 2010, 88, 851-856. [CrossRef] [PubMed]

36. Ryu, H.; Walker, J.K.; Kim, S.; Koo, N.; Barak, L.S.; Noguchi, T.; Kang, B.Y.; Kim, K.M. Regulation of M2-type pyruvate kinase mediated by the high-affinity IgE receptors is required for mast cell degranulation. Br. J. Pharmacol. 2008, 154, 1035-1046. [CrossRef]

37. Dietrich, T.; Ower, P.; Tank, M.; West, N.X.; Walter, C.; Needleman, I.; Hughes, F.J.; Wadia, R.; Milward, M.R.; Hodge, P.J.; et al. Periodontal diagnosis in the context of the 2017 classification system of periodontal diseases and conditions-implementation in clinical practice. Br. Dent. J. 2019, 226, 16-22. [CrossRef]

38. Hajishengallis, G. Immunomicrobial pathogenesis of periodontitis: Keystones, pathobionts, and host response. Trends Immunol. 2014, 35, 3-11. [CrossRef] 
39. Barros, S.P.; Williams, R.; Offenbacher, S.; Morelli, T. Gingival crevicular fluid as a source of biomarkers for periodontitis. Periodontol 2000 2016, 70, 53-64. [CrossRef]

40. Tsuchida, S.; Satoh, M.; Umemura, H.; Sogawa, K.; Kawashima, Y.; Kado, S.; Sawai, S.; Nishimura, M.; Kodera, Y.; Matsushita, K.; et al. Proteomic analysis of gingival crevicular fluid for discovery of novel periodontal disease markers. Proteomics 2012, 12, 2190-2202. [CrossRef]

41. Bostanci, N.; Selevsek, N.; Wolski, W.; Grossmann, J.; Bao, K.; Wahlander, A.; Trachsel, C.; Schlapbach, R.; Ozturk, V.O.; Afacan, B.; et al. Targeted Proteomics Guided by Label-free Quantitative Proteome Analysis in Saliva Reveal Transition Signatures from Health to Periodontal Disease. Mol. Cell Proteom. 2018, 17, 1392-1409. [CrossRef]

42. Carneiro, L.G.; Nouh, H.; Salih, E. Quantitative gingival crevicular fluid proteome in health and periodontal disease using stable isotope chemistries and mass spectrometry. J. Clin. Periodontol. 2014, 41,733-747. [CrossRef] [PubMed]

43. Tsuchida, S.; Satoh, M.; Kawashima, Y.; Sogawa, K.; Kado, S.; Sawai, S.; Nishimura, M.; Ogita, M.; Takeuchi, Y.; Kobyashi, H.; et al. Application of quantitative proteomic analysis using tandem mass tags for discovery and identification of novel biomarkers in periodontal disease. Proteomics 2013, 13, 2339-2350. [CrossRef] [PubMed]

44. Davis, I.J.; Jones, A.W.; Creese, A.J.; Staunton, R.; Atwal, J.; Chapple, I.L.; Harris, S.; Grant, M.M. Longitudinal quantification of the gingival crevicular fluid proteome during progression from gingivitis to periodontitis in a canine model. J. Clin. Periodontol. 2016, 43, 584-594. [CrossRef] [PubMed]

45. Bostanci, N.; Heywood, W.; Mills, K.; Parkar, M.; Nibali, L.; Donos, N. Application of label-free absolute quantitative proteomics in human gingival crevicular fluid by LC/MS E (gingival exudatome). J. Proteome Res. 2010, 9, 2191-2199. [CrossRef] [PubMed]

46. Thorbert-Mros, S.; Larsson, L.; Berglundh, T. Cellular composition of long-standing gingivitis and periodontitis lesions. J. Periodontal. Res. 2015, 50, 535-543. [CrossRef] [PubMed]

47. Li, W.; Zhang, Z.; Wang, Z.M. Differential immune cell infiltrations between healthy periodontal and chronic periodontitis tissues. BMC Oral Health 2020, 20, 293. [CrossRef]

48. Lakschevitz, F.S.; Aboodi, G.M.; Glogauer, M. Oral neutrophil transcriptome changes result in a pro-survival phenotype in periodontal diseases. PLoS ONE 2013, 8, e68983. [CrossRef]

49. Wright, H.J.; Chapple, I.L.; Matthews, J.B.; Cooper, P.R. Fusobacterium nucleatum regulation of neutrophil transcription. J. Periodontal. Res. 2011, 46,1-12. [CrossRef] 